\title{
Analysis of Foreign Direct Investment Policy in India Meena Mansi*
}

Nalsar University of Law, India

*Corresponding author: Meena Mansi, Nalsar University of Law, India, Tel: +914023498385; E-mail: meenamansi2000@gmail.com

Received Date: Mar 23, 2018; Accepted Date: Nov 06, 2018; Published Date: Nov 13, 2018

Copyright: (C) 2018 Mansi M, This is an open-access article distributed under the terms of the Creative Commons Attribution License, which permits unrestricted use, distribution, and reproduction in any medium, provided the original author and source are credited.

\begin{abstract}
Start-ups play a crucial role for the world as they cultivate the innovation of new ideas by the younger generation. This paper focuses upon the scheme of startups that has been introduced for the first time amongst the consolidated Foreign Direct Investment policy that has been in effect from August 2017. The paper starts off by explaining the operation of FDI, Make in India and startups. The intent and objectives laid down by the policy makers are specified in order to compare as to till what extent they are achieved after enforcement of the policy. The relation of GDP and economic growth is explained along with the main and usual challenges that are faced in order to set a startup. In the later section of the paper, pros and cons of the policy are discussed, keeping focus upon how the policy lacks to impact one of the most influential sector of the nation, the agrarian field. In the last segment, the writer has tried to justify, explaining with a comparative model as to why India is not the most ideal place for implementation of such policies and how this ideality can be achieved.
\end{abstract}

Keywords: Globalization; Employment; Financial services

\section{Introduction}

The policy of Foreign Direct Investment (FDI) provides a mechanism of investment in an enterprise in one nation by another enterprise in another nation [1]. In our generation which typically represents the trend of globalization, FDI acts as the bridge to fill in the lacuna between saving and investment of resources and thus, plays one of the most essential roles in the growth of both developed countries as well as developing countries. It aims to increase the efficiency of the rate of input as well as output (which includes existing capacity of production along with the new capacity of production that will be generated). In a way, it also helps in saving the domestic constraint and brings in the superior or ideal technology required for the venture from foreign. This policy proposed by the government has led to benefit of the consumers by introducing more efficient, technologically driven and innovative products in the market. Moreover, the income of a nation is also affected as it produces employment opportunities and introduces new skills which aim to extend the new markets which are developed during the process. Such a policy plays a very crucial part in the countries which are developed because it helps in focusing on the new markets which have the potential of high profits, copious labor, scope for products, etc. However, in our country which is a developing one, the liberalization of such policies is required to welcome more flow of investment from other countries which have bountiful amount of capital resources.

The consolidated FDI policy which has been in effect from 28th of August 2017 directs towards liberalization norms and has brought in some key changes which include [2] :

- FDI in LLPs

- Downstream investment intimation

- Cash and carry wholesale form of trading

- FDI in one single brand retailing

- FDI in e-commerce
- Fresh approval for additional FDI

- FDI linked with the performance conditions

- Foreign Investment Promotion Board (FIPB) abolishment

- FDI in start-ups

- Pension sector

- FDI in other financial services

- FDI in infrastructure companies in the securities market

- Liberalization in:

-Defense

-Pharmaceuticals

-Broadcasting

- Deferred consideration

- Remittance against pre-incorporation expenses.

Under the purview of Make in India, Prime Minister Narendra Modi has introduced the initiative of Start-up India with the ambition to set forth:

"Inspiration and strength to the younger generation of India which is talented and intends to do new things for humanity as well as the nation [3]."

This initiative directs towards creating a platform where the promising entrepreneurs achieve the ability to establish themselves smoothly into the market and receive funding support as well as incentives in the fields which deal with law and simplification of the whole business of startup.

This paper specifically focuses on startups and the consolidated policy of FDI which has come into effect from August 2017. This is for the first time that startups have been included amongst the policies of FDI. According to the rules, startups have been given the ability to raise up to complete $100 \%$ of funds from Foreign Venture Capital Investor (FVCI). Earlier, they could only issue equity or instruments linked to equity or debt instruments to FVCI against the receipt of 
Page 2 of 4

foreign payment but now, a startup can issue convertible notes to the foreign investors. By this, the startup company can issue the corroboration receipt of money which was initially taken as debt as now to an asset which is repayable at the recourse of the holder or allows conversion into equity shares of the startup company, within the time limit of five years which starts on the date of the issue of the convertible note. So basically, the balance of loan taken can automatically be converted to such number of equity shares at that particular moment which is usually after the valuation of a funding round that takes place later on [4]. This entire task is aimed at providing the investors a friendly environment who are foreign contenders and in turn it is expected to attract more FDI which will consequently provide more job opportunities and boost our economic development. The policy has also intended to simplify the denotation of 'venture capital funds' simply as the funds which are registered under the Securities and Exchange Board of India or SEBI (Venture Capital Funds) Regulations 1996 [5]. Earlier the foreign contenders had to maintain a $51 \%$ stake in the respective company where they invest but now, startups have been permitted to take forward losses till the extent where the promoters have the capacity to retain their holding in the venture or company [6].

\section{Intent and Objective of the Policy}

The main aim of the consolidated policy is to ensure more ease at doing business in India and to provide with a friendly atmosphere to the foreign investor in order to pull more FDI in the country. However, the policy specifically mentions two objectives:

Upgrade and attract foreign direct investment so as to supplement domestic capital, skills and technology to direct acceleration towards the wholesome economic growth of the country. The document also states the difference between this from portfolio investment which is dependent upon - lasting interest (in form of a resident) than merely as an investor in the venture.

To issue a regular circular which talks about the consolidated policies of FDI in form of press releases/notes, regulations, clarifications, etc. so as to maintain transparency and predictability and so, it becomes easier for the foreign company to comprehend the rules.

\section{Economic Analysis}

According to the report published by the World Bank in 2016 -

"out of 189 countries India is ranked 130th on the ease of doing business, 157th on the ease of paying of taxes, 133rd on the ease of trading across nations and 155th on the manifestation to start a business. On an average, for any business venture 243 hours are required to be spent so as to prepare and pay taxes, and finish 33 tax payments annually. In contrast, a business holder in our neighboring nation, China just needs to make nine tax payments in one year while in the United States only 11 tax payments are required. However, among the South Asian countries, our nation has made a significant amount of improvement whether business regulations are considered [7]."

The main challenges faced by a foreign investor in any startup company generally include sustainability, security (now growing in terms of cyber space), financial (market structure and rules of the nation in which they are investing), social and cultural awareness (in terms of consumer consumption and behavior).

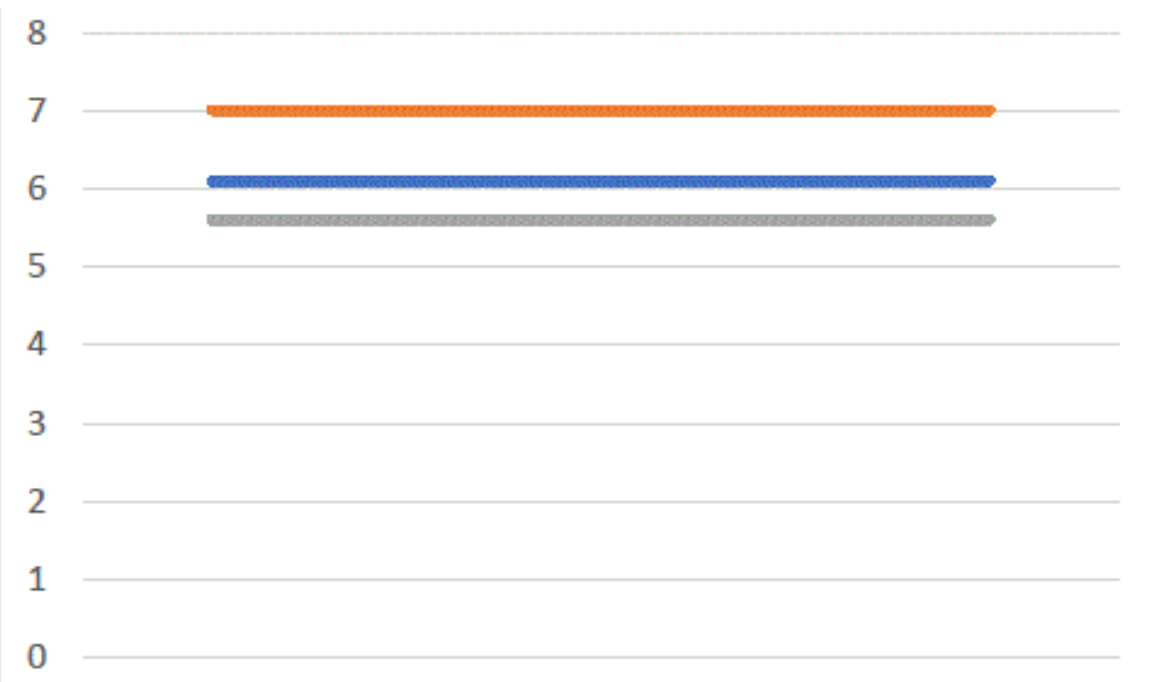

Figure 1: World Bank Report on GDP of India 2016-17.

As shown in Figure 1, the gross domestic product growth in India during January-March 2016-17 was 6.1 percent which is lower than the provisional figure which was 7 percent and 5.6 percent was the fall in the gross value-added growth. The data on gross fixed capital formation also showed that there was a lower off-take of consumer durables as well as the capital goods. Thus, with such a trend where the companies are not able to sell their commodities will definitely have a tendency to enroll less people consequently leading to lesser creation of jobs. Nonetheless, whether inflow of FDI is considered, India is one of the ten nations in the world, and 4th in Asia. Our flow of FDI has increased from 35 billion dollars in 2014 to 44 billion dollars in 2015. All of this progress can be credited to campaigns introduced by the government such as - 'Make in India', 'Startup India' and 'Digital India' and other effects can be concluded on the implementation of 
Page 3 of 4

GST (Goods and Services Tax) including the allowance of 100\% FDI in LLPs (limited liability partnerships) [8].

\section{Downfall of the policy}

The budget of 2018 has specifically focused the most upon the agriculture sector because our economy is still, highly dependent on it [9].

Firstly, there is asymmetry in the flow of FDI into startups, areawise. There is accumulation of investment in the metro cities with a very small portion having find its way to the rural areas of India. Henceforth, this liberalization of FDI policy concerning startups may become a regime that is beneficial in the already urban areas through the automatic pathway but, may fail to achieve the wider domain of socioeconomic objective of creating job opportunities in areas where it is inherently required. This leads towards hastening of the prevailing spatial income inequality. Thus, the very purpose of 'wholesome' development of the country is defeated and a large amount of opportunity cost is lost. Secondly, foreign investors will naturally invest into those startups in India which are globally recognized (or at least in that nation where the investor comes from). Now, such startups characteristically have enough financial support and so, investments are gathered into those selected few successful or promising startups, setting off the many other startups which have very limited financial backup. Such an operation has a tendency to make the market imperfect in the sphere of startups through consolidation and acquisition. Thirdly, when non-domestic investors invest, they definitely do not simply want the business to develop in India; their ulterior motives include getting benefitted from that investment. This consequence makes way for the benefit of opportunities created in India to be harvested by the foreigners. Even P. Chidambaram, former Union Minister for Finance and Home Department said:

"FDI policy is such that it gives too much economic scope of the Indian market into the hands of foreign investors [10]."

\section{Benefits of the policy}

Firstly, due to investment by foreign companies in our startups, new and better technology is carried along with the capital resources that they provide us. This leads to innovative products with increased efficiency which gives more choices to the consumer in the Indian market. Thus, the consumer can evaluate the opportunity cost of the products and purchase them accordingly. Secondly, better production leads to increase in the Gross Domestic Product (GDP) of the nation. GDP is the market value of all final services and commodities within a nation during a particular period of time. It measures the total income of everybody in the economy [11].

Thirdly, more inflow of FDI gives the opportunity to the India rupee to rise in the market it shown in the Figure 2.

Foreign investor's choice $=\mathrm{F}$ (Indian rupee, market, consumers, labor, etc.)

The investors invest in the market with a belief that they will get good returns through their investment on the Indian Rupee. There is a purchase of corporate and government bonds and these bonds are bought against the foreign currency. From the Figure 3 Consequently, all of this results to an increase in the INR. Thus, FDI indirectly results in the appreciation of the Indian Rupee.

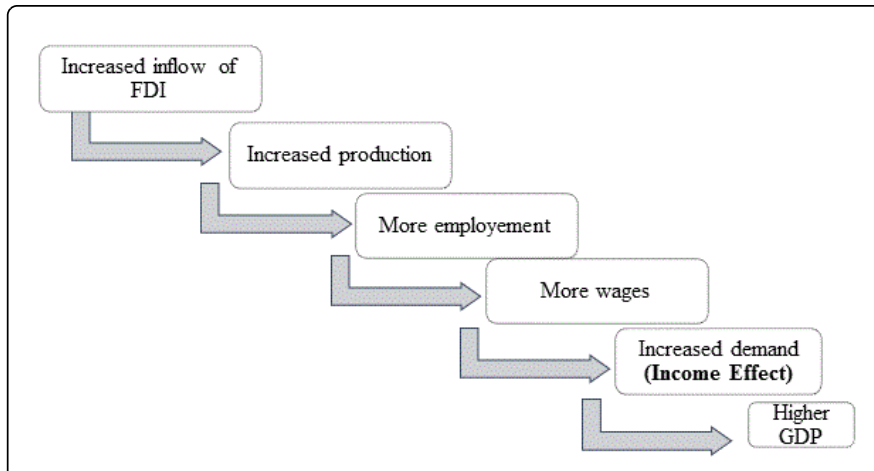

Figure 2: Increase in the Gross Domestic Product (GDP) of the nation.

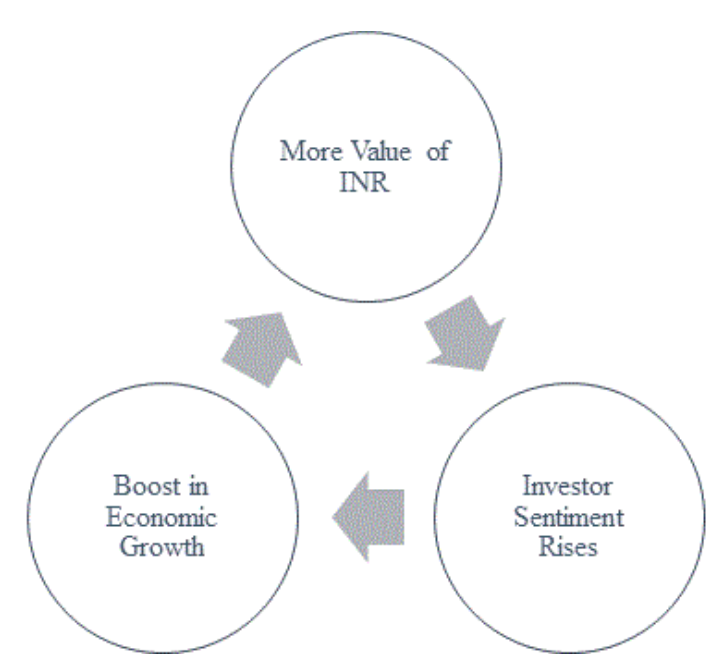

Figure 3: Appreciation of the Indian rupee.

\section{How can implementation be made more efficient in India?}

First and foremost, the government should focus upon providing a better infrastructure. Our one of the biggest issues as to why the foreign investors hesitate to invest into the startup industries or factories is due to the issue of lack of adequate supply of electricity because the already built business ventures have enough finance to avoid this error of lack of electricity. A startup just cannot work without electric supply and power cuts are one of the major cruxes of problem as to why there is less investment, especially in the rural areas. Secondly, a decrease in the rate of corruption would lead to better investment as well as startup opportunities. It is easier for a startup to sustain with FDI in a nation such as Singapore or Hong Kong because of the less corruption rate as compared to India [12]. Thirdly, although corporate tax rates avoid unnecessary liberty to the foreign investors but high corporate tax rate can be a major disincentive to the foreign corporate investment in our country [13]. This is why it is difficult to invest in a startup which is based in UAE and easier for a startup based in Europe [14]. Lastly, there has to by uniformity in the policies. Investors necessarily take less interest to invest in such a place where there is political instability because one government may favor one policy and once the government changes, the new one may bring a 
Page 4 of 4

policy completely opposite of the one existing. Hence, if there is more evenness then it becomes less risky for the investor to invest.

\section{Conclusion}

The main aim of the researcher of the paper was to analyze the policy of FDI, keeping the main focus upon the scheme of startup which was introduced for the very first time. Producing and exchanging services in which you have your highest absolute advantage as well as comparative advantage results in an efficient market. This is what FDI has tried to provide the economic market with. The researcher has tried to compare the intent laid down by the policy makers and the objectives achieved after the implementation of the policy. The paper notes down that the biggest defeat of the policy is because of the fact that the scheme is not connected to the pathway that leads to improvement in the agriculture sector. Though its biggest benefit is that it helps in increasing the Gross Domestic Product of the country. Thence, there are pros as well as cons of the policy and so, the researcher has also tried to provide with an explanation as to why India lacks being an ideal place for the implementation of the policy and how more efficiency can be achieved under substantial improvement in the conditions.

\section{References}

1. Abhishek VV (2015) An Analytical Study of FDI in India. International Journal of Scientific and Research Publications 5: 1-30.

2. Consolidated FDI Policy Circular of 2017, Government of India.

3. Startup India(2018) A Nurturing Force, Make In India..

4. Convertible Note (2018) Funders Club.

5. Securities and Exchange Board of India (Venture Capital Funds) Regulations 2016.

6. Kashyap K (2018) Four sectors of Indian Startups that have gained from Budget 2017. Forbes.

7. World Development Report (2016) World Bank.

8. Banik N, Chandra K (2018) As India's Economic Indicators Slump, FDI Inflows Have Never Looked Better. Why? The Wire.

9. Jaitley A (2018) Budget 2018-19. Government of India, pp: 1-32.

10. Chidambaram takes a dig on FDI (2015) TOI.

11. Brooks W (2018) Gross Domestic Product.

12. Transparency International Corruption Perceptions Index 2016. EY, pp: $1-9$.

13. Agnes BQ, Lionel F, Amina LR (2018) How does FDI react to Corporate Taxation. pp: 1-35.

14. Jahnsen K, Pomerleau K (2018) Corporate IT rates around the world, 2017. Tax Foundation. 